\title{
SISTEM EKONOMI KAPITALISME
}

Oleh: Muthia Zhafirah Ali (90100118037)

email:vhiraphila2@gmail.com

Sejarah dari sistem ekonomi kapitalisme muncul di Eropa pada abad ke-16. Kapitalisme di Eropa muncul dari pemikiran kaum ilmiah yang ada pada awalnya berfikir untuk mensejahterakan kaum buruh. Max Weber dalam karyanya The Protestan Ethic of Spirit Capitalism, mengungkapkan bahwa kemunculan kapitalisme erat sekali dengan semangat religious terutama kaum protestan. Kapitalisme awal dimulai dengan lahirnya institusi pasar pada abad ke-16 dan dilanjutkan dengan perkembangan perdagangan jarrak jauh antar pusat-pusat kapitalisme dunia. (Huda, 2016)

Sistem ekonomi kapitalisme merupakan sebuah sistem atau organisasi yang dicirikan oleh hak milik privat atas alat-alat produksi untuk mencapai laba yang sangat kondusif. Sistem ekonomi kapitalisme juga dapat dikatakan sebuah sistem yang faktor-faktor produksinya dimiliki oleh individu atau swasta. Dapat dikatakan sistem ekonomi kapitalis memberikan kebebasan secara penuh kepada setiap orang untuk melakukan kegiatan ekonomi. Contohnya menjual, memproduksi, menyalurkan barang. Di dalam sistem ekonomi kapitalisme yang berperan adalah individu bukan pemerintah. Pemerintah hanya bertugas untuk memberikan pajak agar dapat mensejahterahkan rakyatnya. Perekonomian kapitalisme setiap warga negara bertanggung jawab atas dirinya sendiri atau mengatur nasibnya sesuai dengan kemampuannya. (Radlyah Hasan Jan, 2008)

Sistem ekonomi kapitalisme berdiri dengan dipengaruhi oleh tiga tokoh besar yaitu Adam Smith, Marthin Luther dan Benjamin Franklin. Sistem ekonomi kapitalisme dikenal sebagai pola perekonomian dunia terkait erat dengan sistem kolonialisme. Adam Smith selaku pemikir dari sistem ekonomi kapitalisme memberikan teori-teori pemikiran tentang mekanisme pasar yakni menghendaki setiap orang untuk diberikan kebebasan berusaha dalam persaingan perekonomian. (Zainol Hasan \& Mahyudi, 2020) Tokoh-tokoh mazhab klasik mengemukakan bahwa segala kegiatan ekonomi yang dilaksanakan secara bebas 
dinilai akan lebih banyak manfaatnya bagi kalangan masyarakat sebagai keseluruhan dibanding jika pemerintah ikut campur tangan didalamnya. (Agustiati, ISSN 1411-3341)

Menurut Muhammad Sharif Chaudhry kelemahan dari sistem ekonomi kapitalisme yakni:

1. Dari segi hak milik yang menyadarkan hak pemilikan kepada swasta untuk dijadikan sebagai alat produksi, distribusi dan penukaran.

2. Dari segi kebebasan ekonomi yang tidak terbatas dan tidak ada campur tangan dari negara. Sehingga menimbulkan pemikiran untuk mendapatkan harta dengan cara yang curang atau tidak adil seperti judi dan pelacuran.

3. Dari segi monopoli yang sangat memuja persaingan sehingga menimbulkan terjadinya merger beberapa bisnis kecil menjadi satu sehingga menjadi monopoli atau kartel. Akibatnya sistem ekonomi seperti akan membunuh persaingan bebas dan juga menyebabkan terjadinya inflasi.

4. Dari segi kekayaan yang kepemilikan alat-alat produksi oleh individu atau swasta maka otomatis perbedaan akan muncul. Perbedaan hak yang sangat mencolok antara majikan dan pekerja akan menyebabkan masyarakat terbelah menjadi dua kelompok yang bersaing dan saling menjatuhkan satu dengan yang lain.

Sistem ekonomi kapitalisme nyata-nyata dibangun dari sebuah ide sekularisme yang memisahkan kehidupan masyarakat dan bernegara dengan agama (fashlu al-din 'ani alhayat). Paham ini intinya memandang bahwa manusia hidup ini di dunia bebas untuk mengatur kehidupannya dan tidak boleh dicampuri oleh agama. Karena nilai-nilai agama juga ditiadakan, maka sudah pasti nilai moral dan spiritual yang menjadi basis dari agama juga ditiadakan. (Amri, 2017) Padahal jika menurut pandangan Islam, dalam sistem ekonomipun harus disandarkan dengan agama yang dimana suatu sistem ekonomi harus berjalan sesuai dengan syari'at Islam. Sejak awal sejarah manusia, orang-orang bekerja keras dalam kehidupan untuk memenuhi terjaminnya barang dan jasa dan memanfaatkan nikmat-nikmat yang Allah swt. berikan. Artinya segala sesuatu kenikmatan yang diberikan di dunia datangnya dari Allah swt. (Emily, 2017) 


\section{DAFTAR PUSTAKA}

Amri, H. (2017). Kelemahan sistem ekonomi kapitalisme dan sosialisme menurut Muhammad Sharif Chaudhry dalam karyanya fundamental of Islamic economic system. Economica Sharia, 2(2), 1-16.

Radlyah Hasan Jan. (2008). Eksistensi Sistem Ekonomi Kapitalis di Indonesia, 1-2.

Huda, C. (2016). Ekonomi Islam Dan Kapitalisme (Merunut Benih Kapitalisme dalam Ekonomi Islam). Economica: Jurnal Ekonomi Islam, 7(1), 27-49.

Agustiati. (2018). Sistem Ekonomi Kapitalisme di Indonesia. ISSN 1411-3341.

Zainol Hasan, \& Mahyudi, M. (2020). Analisis terhadap Pemikiran Ekonomi Kapitalisme Adam Smith. Istidlal: Jurnal Ekonomi Dan Hukum Islam, 4(1), 24-34.

Nur Saidy, Emily. (2017). Uang Dalam Tinjauan Ekonomi Islam. Laa Maisyir, 6(2), 26. 